\title{
30. UPPER MIOCENE TO PLEISTOCENE CLIMATES IN NORTHWEST AFRICA DEDUCED FROM TERRIGENOUS COMPONENTS OF SITE 397 SEDIMENTS (DSDP LEG 47A)
}

\author{
Hervé Chamley, ${ }^{1}$ Geologie marine, Luminy, 13288 Marseille cx. 2, France \\ and \\ Liselotte Diester-Haass, Geologisches Institut der Universität, 23 Kiel, West Germany
}

\begin{abstract}
A comparison of the clay mineralogy in fractions $<2 \mu \mathrm{m}$ and the amount of terrigenous components and desert quartz numbers in fractions $>40 \mu \mathrm{m}$ of Site 397 sediments allows a reconstruction of Neogene climatic conditions on the African continent in the latitude of Cape Bojador. Arid climates generally are marked by relatively high contents of chlorite, attapulgite (palygorskite), and quartz; humid climates have substantial amounts of irregular mixed-layers and terrigenous sandy particles. Arid and humid periods alternated in the late Miocene, with the arid periods lasting longer. Transport energies were not very strong during the late Miocene. The Pliocene had a generally arid climatic environment without rivers, but some small-scale variations in humidity are revealed by clay mineral analysis. The transport energy was low, leading to a discrepancy between results from coarse fraction and clay-sized material. The Pleistocene is characterized by numerous and strong changes between humid periods (with river supply, soil formation, and degradation of clay minerals) and arid periods (with eolian supply of coarse and finegrained terrigenous particles). Transport energy was high, leading to parallel variations of coarse and fine-grained terrigenous components.
\end{abstract}

\section{INTRODUCTION}

Site 397 is located south of the Canary Islands $\left(26^{\circ} 50.7^{\prime} \mathrm{N}, 15^{\circ} 10.8^{\prime} \mathrm{W}\right)$ in a 2900 -meter water depth; the total penetration was 1453 meters sub-bottom. The site has been sedimentologically studied from various points of view (see Site 397 Chapter). Among these, the detailed study of the coarse fraction of Neogene hemipelagic deposits has led to conclusions regarding the conditions of shallow water sediment supply, climate, upwelling, calcium carbonate dissolution, and volcanism (Diester-Haass, this volume). The routine mineralogical analysis of the clay fraction has provided data about terrigenous supply, diagenesis, climate, and sedimentation dynamics (Chamley and Giroud d'Argoud, this volume). The purpose of this report is to compare the results of both methods for a climatological interpretation of the "autochthonous" hemipelagic upper section of the hole ( 0 to $534.5 \mathrm{~m}$, Cores 1 to 56). We selected 76 samples for this joint study that includes pretrographic analysis of the $>40 \mu \mathrm{m}$ fraction and the mineralogical study of the $<2 \mu \mathrm{m}$ fraction. The methods used here are described elsewhere in this volume (Diester-Haass; Chamley and Giroud d'Argoud).

' Present address: Sédimentologie et Géochimie, Université Lille I 59650 Villeneuve d'Ascq, France.

\section{COARSE FRACTION ANALYSIS}

The terrigenous supply from northwestern Africa to the Atlantic Ocean is concentrated in the clay and silt fraction. Terrigenous components in the $>40 \mu \mathrm{m}$ fraction are rare and sensitive to changes in transport mechanisms and transport energies. The $>40 \mu \mathrm{m}$ fractions contain quartz and much lesser amounts of mica, feldspars, and other minerals. The amount of terrigenous components has been counted in the 40 to 63,63 to 125 , and $>125 \mu \mathrm{m}$ fractions (Diester-Haass, this volume). Only the amounts in the 40 to $63 \mu \mathrm{m}$ fraction are considered in this report (Figure 1). Quartz grains often show red staining, attributed to a desert environment (Norris, 1969; Walker, 1967). They are considered to be "tracers of arid climate" (Diester-Haass, $1975,1976)$ and are plotted as desert quartz numbers: (red stained quartz/colorless quartz) $\times 100$.

Three subdivisions are discernible in two graphs in Figure 1 that show the amount of terrigenous components in the 40 to $63 \mu \mathrm{m}$ fraction and the desert quartz numbers. In Cores 2 to 15 , there are strong variations between high amounts of terrigenous material correlated to low desert quartz numbers, and layers with small amounts of terrigenous material correlated to high desert quartz numbers. From Cores 16 to 43 terrigenous input is generally low and the desert quartz numbers are significantly higher than in the upper part. 


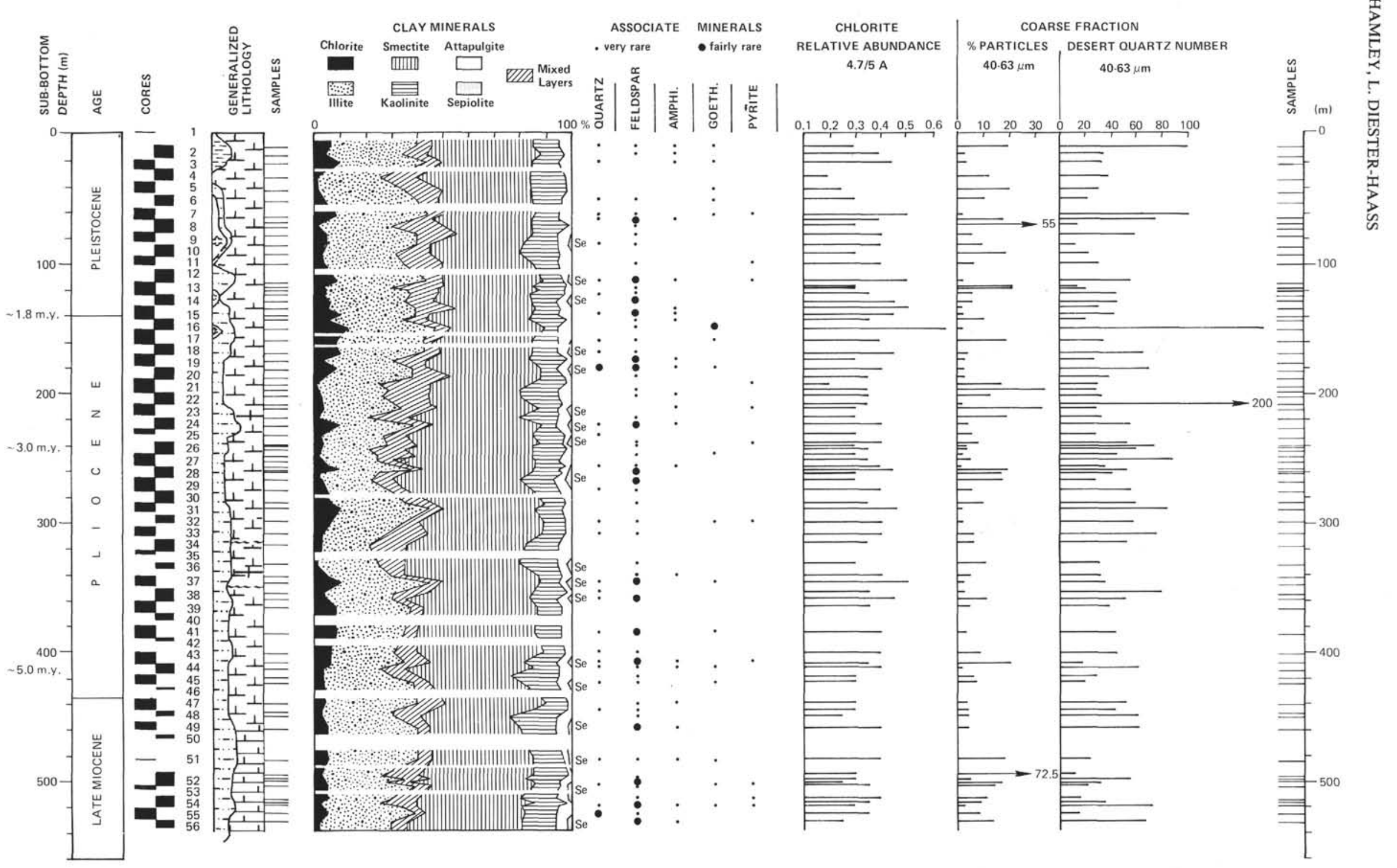

Figure 1. Site 397, DSDP Leg 47A. Data of clay mineralogy and coarse fraction study. 
This trend becomes clearer when considering all investigated samples, not just the 76 samples from this comparative study (see Diester-Haass, this volume, fig. $1 \mathrm{j}$, k). The samples with highly increased terrigenous input in Cores 21 to 24 , which correlate with high desert quartz numbers, are interpreted as eolian sand turbidites (Diester-Haass, this volume) and cannot be compared with the other samples, which originated from normal hemipelagic sedimentation. Cores 44 to 56 also show variations between small terrigenous input with high desert quartz numbers and high terrigenous supply with low desert quartz numbers; but the variations are not as strong as in the Pleistocene.

In the late Quaternary sediments off northwestern Africa, periods with small amounts of terrigenous input $>40 \mu \mathrm{m}$ and high desert quartz numbers can be correlated to an arid climate on the continent and an eolian supply. High terrigenous input and decreasing or disappearing desert quartz can be attributed to increasing rainfall, leading to soil formation, plant growth (Agwu, 1976), and river formation yielding fluviatile sediment input (Diester-Haass, 1975, 1976; Diester-Haass et al., 1973; Chamley et al., 1977). If these results can be applied to the Neogene sequence, one can conclude that the late Miocene had a climate with changes between prolonged arid and shorter humid periods. The Pliocene was arid with low wind strenghts, based on evaluation of low terrigenous input. The early Pleistocene was rather arid with only the upper part of the Pleistocene sequence indicative of strong and rapid changes between arid and humid climates; similar conclusions have been previously derived from late Quaternary sediments from the same area.

\section{CLAY FRACTION ANALYSIS}

The mineralogical assemblage of the $<2 \mu \mathrm{m}$ noncalcareous fraction is diverse (Figure 1). The generally well-crystallized smectite is slightly more abundant than illite. Kaolinite and irregular mixed layers (illitesmectite and, less often, chlorite-smectite or illitevermiculite) are fairly abundant. Chlorite and attapulgite are present throughout the sequence (traces to $10 \%$ each), and traces of sepiolite occur frequently. The associate minerals are represented by ubiquitous feldspars, frequent quartz, episodic amphiboles, goethite, and pyrites.

The origin of all the clay assemblage is detrital (Chamley et al., 1977; Diester-Haass and Chamley, in press; Chamley, this volume). This is especially true for those minerals of variable origin, such as smectite and fibrous clays. Smectite in mainly inherited from badly drained soils developed under an arid climate with contrasting seasons (Paquet, 1969). Fibrous clays (attapulgite, sepiolite) are chiefly derived from the erosion of Paleogene sedimentary rocks amply outcropping on the African shield (Millot, 1964; Chamley, 1971; Chamley and Millot, 1975). In general, the clay minerals have an African origin, as shown by the latitudinal parallelism between offshore and onshore clays (see Millot, 1964; Griffin et al., 1968; Pédro, 1968; Chamley et al., 1977). A main supply from the northeast through trade winds and the Canary current is probable; this explains the relatively high content of chlorite, probably supplied from the Atlas Mountains by the river Oued Draa. Moreover, this supply from the northeast explains the lack of a smectite increase in the late Miocene, as seen elsewhere (see Chamley et al., 1978, in press; Diester-Haass and Chamley, in press). The mineral could not be formed in the soils because of the tectonic instability of the Atlas during this period (Dillon and Sougy, 1974).

The clay mineralogy in the hemipelagic series of Site 397 does not show any noticeable progressive downhole trend. This proves that diagenesis with increasing depth is absent or very weak. Besides, these variations are not related to sedimentological or petrographical peculiarities, such as the presence of volcanic material. Consequently, they represent fluctuations in the terrigenous supply. The observed changes follow two leader minerals, chlorite and mixed layers, that vary in opposite manners. When chlorite increases, an increase of attapulgite and partly of illite, sepiolite, feldspars, quartz, amphiboles, and iron oxides can be observed. When mixed layers increase, they are more or less closely followed by kaolinite and smectite. This general trend is illustrated (Figure 1) by the chlorite relative abundance $(4.7 / 5.0 \AA$ peak height ratio, Chamley, 1971). The fluctuations of both mineralogical groups are strong and numerous in the Pleistocene and latest Pliocene (Cores 1 to 20), somewhat marked in the Pliocene (Cores 21 to 42 ), and fairly marked in the late Miocene (Cores 43 to 56). This difference becomes particularly evident when considering all the samples submitted to the mineralogical study along the autochthonous section (Cores 1 to 56, 122 samples; Chamley, this volume).

The interpretation of the inverse variations of both mineral groups is the same as that proposed for Pleistocene and Holocene sediments off northwestern Africa (Chamley et al., 1977). The levels relatively rich in chlorite correspond to periods of arid climate on the near continent: low hydrolysis allows the conservation of unstable minerals (like chlorite and attapulgite) and possibly the precipitation of iron oxides (goethite, subamorphous oxides). The more humid periods lead to the pedogenic degradation or destruction of these minerals resulting in pronounced alteration of feldspars, amphiboles, etc., and to the development of degraded mixed layers and kaolinite. Thus, from a mineralogical point of view, the late Miocene to present interval is characterized by a succession of humid and arid stages. The alternation is weakly marked during the Pliocene, with the fair abundance of chlorite pointing to a persistently arid climate. The alternation is fairly marked during the late Miocene, and strongly marked from latest Pliocene to the present, with an increase in the middle and late Pleistocene. The large sample intervals ( $1 / 7.2 \mathrm{~m}$ for the present study; $1 / 4.5$ $\mathrm{m}$ for the routine analysis) do not permit the recognition of all climate fluctuations which are discernible in intervals of 20 to $200 \mathrm{~cm}$ in densely sampled Pleistocene cores (Diester-Haass, 1976; Chamley et al., 1977). 


\section{DISCUSSION}

The comparison of the results from coarse and clay fraction analyses shows a division of the hemipelagic sequence into two parts (Figure 1). The upper part, from the latest Pliocene to the late Pleistocene (Cores 2 to 21), reveals parallel variations of both groups of results. Samples rich in coarse terrigenous particles always have low chlorite and associated mineral contents. This is in agreement with the interpretation of a humid climate on the African continent at the latitude of Site 397. This humid climate is responsible for a rather high terrigenous input, probably by rivers, for the degradation of clay minerals submitted to hydrolysis in soils, and for the absence or diminution of desert quartz. The samples with small amounts of terrigenous components $>40 \mu \mathrm{m}$ and high desert quartz numbers indicate small terrigenous input (mainly by wind) and arid conditions (which inhibit pedogenesis and conserve unstable minerals like attapulgite and chlorite). These parallel variations of clay minerals and coarse terrigenous components have also been found in other upper Pliocene to Holocene sediments off northwestern Africa in the latitude zone of 19 to $27^{\circ} \mathrm{N}$ (Chamley et al., 1977; Diester-Haass and Chamley, in press).

The correspondence between results from the two methods is absent in Cores 24 to 56 (Cores 21 to 23 contain eolian sand turbidites and are not considered here). The $>40 \mu \mathrm{m}$ fractions in the Pliocene sequence contain small amounts of terrigenous components, and high desert quartz numbers indicate an arid climate. Arid and humid periods alternate in the late Miocene. Pliocene clay mineral assemblages reveal high chlorite amounts, indicating an arid environment on the continent. But fluctuations in the clay mineral assemblages occur and have to be interpreted as the result of variations in humidity. In the late Miocene, these variations are stronger than in the Pliocene, but not as strong as in the Pleistocene. They cannot always be related to variations of terrigenous components in the coarse fraction. The same disagreement between coarse and fine terrigenous component can be observed in contemporaneous sediments of Site 141 (DSDP Leg 14; DiesterHaass and Chamley, in press).

The reason for the disagreement between the results of coarse and clay fraction analyses can be found in the size of the investigated particles and the energy necessary for their transport. Clay minerals need only weak transport energies and can easily be distributed in the ocean. The Pliocene climate was arid, as suggested by the coarse terrigenous components. The main transport agent, the wind, had low velocities and was unable to transport significant amounts of terrigenous components $>40 \mu \mathrm{m}$ offshore (Bagnold, 195.4). There probably were no rivers that could supply coarse terrigenous material. But the clay fraction reveals that within the generally arid climate, small variations occurred, mainly with respect to humidity. These small-scale climatic changes influenced the clay minerals in two ways. Firstly, they allowed periodic and moderate degradation of clay minerals in the soils of the areas of the alluvial basins which received most of the humidity. Secondly, the described climatic changes led to the erosion and transport of the superficial clay minerals which easily could reach the slope, even with weak transport energies.

This interpretation suggests that the coarse and clay fraction analyses complement each other in investigations on climatic conditions on the continent and their influence on erosion, transport, and sedimentation of terrigenous particles (Figure 2). When the climate is generally arid and shows only small-scale variations, as during the Pliocene, the dynamics of hydrolysis and transport are sufficient to influence small-sized clay minerals, but too weak to produce significant changes in supply of terrigenous components $>40 \mu \mathrm{m}$. When variations between arid and humid periods become stronger, as in the late Miocene, the $>40 \mu \mathrm{m}$ and claysized particles reveal greater changes in amount and composition, but the correspondence between both groups is still mediocre because of low transport energy. Furthermore, the seasonal distribution of rainfall in this period can strongly influence clay minerals in soils (for details, see Chamley et al., in press a, b). Finally, when climate is clearly alternating between rather humid periods (with enough rainfall to allow river formation) and arid periods (with wind supply, as in the latest Pliocene, the Pleistocene, and the Holocene), the transport energy is high enough to allow parallel variations of both clay-sized and coarsegrained terrigenous components (Chamley et al., 1977; Diester-Haass and Chamley, in press). This parallelism between the results of both methods and the agreement in climatic interpretations begin in Core 24 (21) of Site 397, that is, about 3 m.y.B.P. This coincides with the beginning of a global climatic deterioration (Berggren, 1972; Blank and Margolis, 1975; Shackleton and Kennett, 1975; Watkins and Kennett, 1971; and others) and perhaps with an increase in atmospheric and marine current velocities (Diester-Haass, this volume).

The comparison of the results of coarse-sized and clay-sized terrigenous components leads to a much more precise and detailed reconstruction of Neogene climates than each method could define by itself.

\section{ACKNOWLEDGMENTS}

We thank the scientific shipboard party of Leg 47A for providing samples for the shore-based investigations. The financial support for the mineralogical study was provided by the CNEXO, France (Grant 76/5320). The technical assistance was given by G. Giroud d'Argoud and M. Acquaviva. The financial support for the coarse fraction analysis by the Deutsche Forschungsgemeinschaft is gratefully acknowledged. Thanks are due to W. Schnitzer, Würzburg, for providing working facilities, and to B. Alberts, A. Rongitsch, and R. Schneider for very careful sample preparation. The text was reviewed by U. von Rad, who proposed useful improvements. 


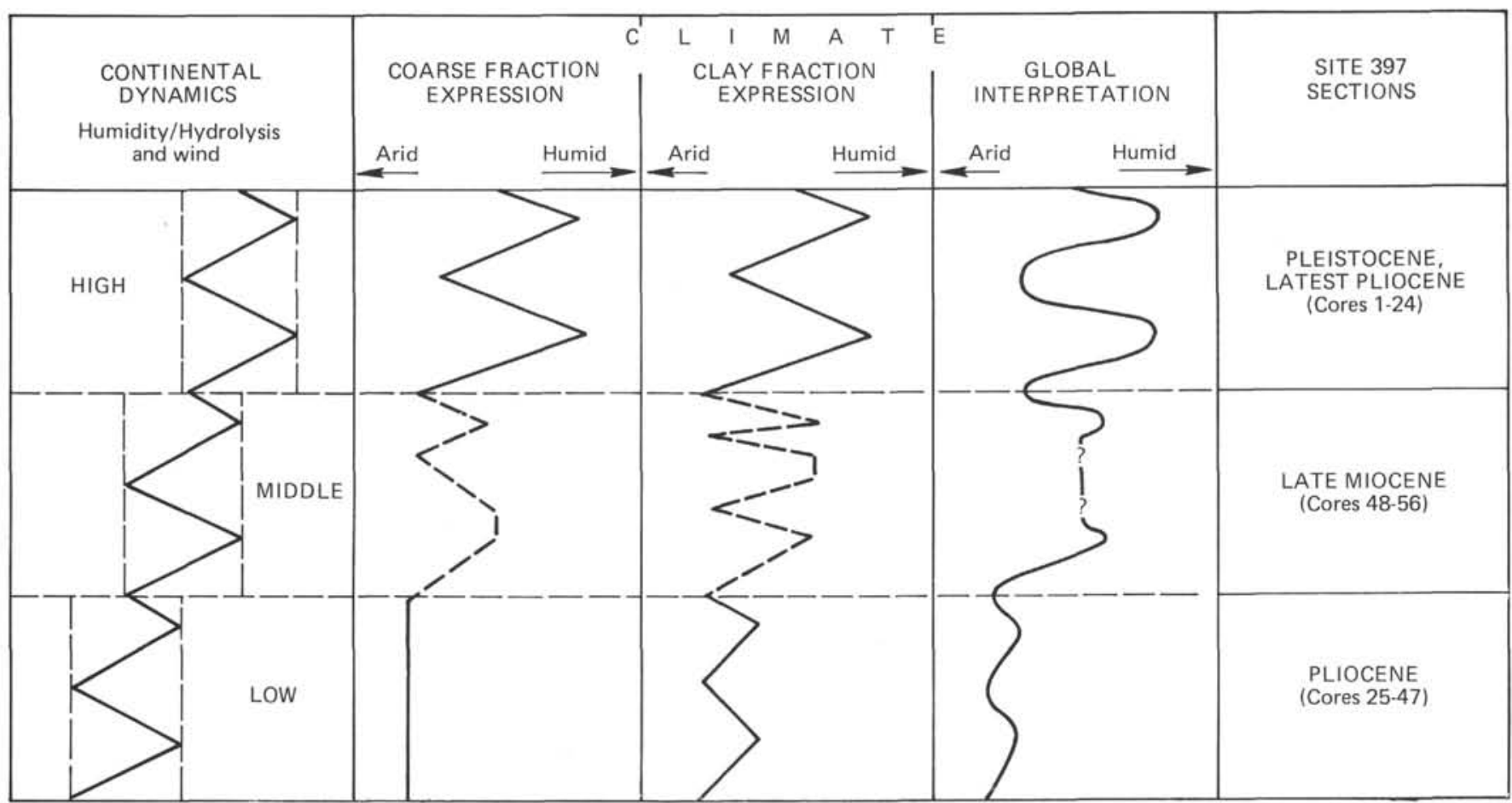

Figure 2. Schematic diagram showing influence of dynamic continental changes on the paleoclimatological features deduced from sandy and clayey sedimentary components. Example of Site 397 Neogene.

\section{REFERENCES}

Agwu, C., 1976. Vegetations- und klimageschichtliche Untersuchungen an marinen Sedimenten von der westafrikanischen Küste. Methodische Grundlagen, Dipl. Arb. Univ. Göttingen, Germany.

Bagnold, R. A., 1954. The physics of blown sand and desert dunes: London (Methuen).

Berggren, W. A., 1972. Late Pliocene-Pleistocene glaciation. In Laughton, A. S., Berggren, W. A., et al., Initial Reports of the Deep Sea Drilling Project, v. 12: Washington (U.S. Government Printing Office), p. 953-963.

Blank, R. G. and Margolis, S. V., 1975. Pliocene climatic and glacial history of Antarctica, as revealed by south-east Indian Ocean deep-sea cores, Geol. Soc. Am. Bull., v. 86, p. 1058-1066.

Chamley, H., 1971. Recherches sur la sédimentation argileuse en Méditerranée, Sci. géol., Strasbourg, France, Mém. 35.

Chamley, H. and Millot, G., 1975. Observations sur la répartition et la genèse des attapulgites plio-quaternaires de Méditerranée, C.R. Acad. Sci., Paris, v. 281, p. 1215-1218.

Chamley, H., Diester-Haass, L., and Lange, H., 1977. Terrigenous material in East Atlantic sediment cores as an indicator of NW African climates, Meteor Forschungsergebnisse, v. 26 , p. $44-59$.

Chamley, H., Dunoyer de Segonzac, G., and Mélières, F., 1978. Clay minerals in Messinian sediments of the Mediterranean area. In Hsü, K. J., Montadert, L. C., et al., Initial Reports of the Deep Sea Drilling Project, v. 42, Part 1: Washington (U.S. Government Printing Office), p. 389.

Chamley, H., Giroud d'Argoud, G., and Robert, C., in press. Genèse des smectites messiniennes de Sicile. Implications paléoclimatiques, Géol. méditerr., Marseilles, France.
Diester-Haass, L., 1975. Sedimentation and climate in the Late Quaternary between Senegal and the Cape Verde Islands, Meteor Forschungsergebnisse, v. 20, p. 1-32. 1976. Late Quaternary climatic variations in Northwest Africa deduced from East Atlantic sediment cores, Quatern. Res., v. 6, p. 299-314.

Diester-Haass, L., and Chamley, H., in press. Neogene paleoenvironment investigations off NW Africa (DSDP Leg 14), J. Sediment. Petrol.

Diester-Haass, L., Schrader, H. -J., and Thiede, J., 1973. Sedimentological and paleoclimatological investigations of two pelagic ooze cores off Cape Barbas, NW Africa, Meteor Forschungsergebnisse, v. 16, p. 19-66.

Dillon, W. P., and Sougy, J. M. A., 1974. Geology of West Africa and Canary and Cape Verde Islands. In Nairn, E. M. and Stehli, F. C. (Eds.), The ocean basins and margins, v. 2, The North Atlantic, p. 315-390.

Griffin, J. J., Windom, H., and Goldberg, E. D., 1968. The distribution of clay minerals in the world ocean, Deep-Sea Res., v. 15, p. 433-459.

Millot, G., 1964. Géologie des Argiles: Paris (Masson Ed.).

Norris, R. M., 1969. Dune reddening and time, J. Sediment Petrol., v. 39 , p. 7-11.

Paquet, H., 1969. Evolution géochimique des minéraux argileux dans les altérations et les sols des climats méditerranée et tropicaux à saisons contrastées, Mém. Serv. Carte Géol. Alsace-Lorraine, Strasbourg, France, Mém. 30.

Pédro, G., 1968. Distribution des principaux types d'altération chimique à la surface du globe. Présentation d'une esquisse géographique, Rev. Géogr. phys. Géol. dyn., Paris, v. 10 , p. $457-470$.

Shackleton, N. J. and Kennett, J. P., 1975. Late Cenozoic oxygen and carbonate isotopic changes at DSDP Site 284: implications for glacial history of the northern hemisphere and Antarctica. In Kennett, J. P., Houtz, R. E., et al., Ini- 
tial reports of the Deep Sea Drilling Project, v. 29: Washington (U.S. Government Printing Office), p. 801-807.

Walker, T. R., 1967. Formation of red beds in modern and ancient deserts, Geol. Soc. Am. Bull., v. 78, p. 353-368.
Watkins, N. D. and Kennett, J. P., 1971. Antarctic bottom water: major change in velocity during the Late Cenozoic between Australia and Antarctica, Science, v. 173, p. 813-818. 